\title{
Preface: twenty years of ERA
}

\section{Pauliine Koskelo}

Published online: 5 February 2013

(C) ERA 2013

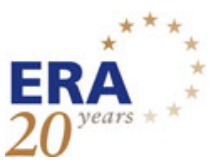

It gives me great pleasure to be able to congratulate ERA on its 20th anniversary. At home I have a daughter who is twenty, and she is lovely. In ERA, I have another close friend at the age of twenty, and this, too is a most admirable friend.

ERA is, first of all, an academy, but without being academic. ERA is an institution for training, for exchange of experience and ideas, and a forum for debate and interaction. ERA draws on the expertise of legal professionals from many different fields and functions - including people from academia but not limited to them - and it brings together audiences from a variety of legal professions, in order to develop and enrich their knowledge and competencies. ERA is characterised by multi-professionalism in its field of activity, and this is one of its major assets.

Secondly, ERA is a European academy. It is today truly cross-European, not just in terms of the reach of its activities in the various Member States, but also in terms of its ability to engage experts and high-level representatives from the European institutions to bring their contributions to the activities and events in the programme.

This combination of multiculturalism, multi-professionalism and "multi-levelism" in ERA's activity is, together with the quality of the programmes, the essence of its contribution to European legal training and debate. The value added is, I think, beyond doubt at this point in ERA's still relatively short but quite impressive history.

Thirdly, and essentially of course, ERA is an academy of law, European law. As we all know, European Union law has evolved into a special kind of legal order,

The article is based on the speech delivered by the author at the congress The citizen at the heart of EU law, organised by ERA to commemorate the 20th anniversary of its foundation on 18-20 October 2012 in Trier.

P. Koskelo, President

Supreme Court of Finland, Pohjoisesplanadi 3, 00170 Helsinki, Finnland 
with unique constitutional features. It has not just undergone various changes and advances here and there, but has acquired quite new dimensions over the years. For ERA, being a European academy of European law is a very important, very exciting and very dynamic role to have, and also a very demanding one.

The theme of this anniversary congress relates to European citizens. When the European Community started out, it was essentially about market freedoms, competition and economic integration in general. But it would be wrong to consider that in those early days the citizens were not at all in focus. For it is obvious that all along, the citizens of Europe have been the intended beneficiaries of European integration. The EU as a long-time peace project has been, and remains, of fundamental existential value to all its citizens. Likewise, the EU as a project of economic welfare and sustainable development was, and is, meant to serve the interests of the citizens. The original and more traditional elements of EU law were, however, of a more indirect and more general nature in their relevance to the citizens than some of the more recent developments and landmarks, many of which concern the citizens more directly as individuals. It is more a matter of focus and angle, and of ways and means, than of fundamental purpose. This congress will deal with the more novel features and layers of EU law that are of direct importance to European citizens.

It would be great to be able to say, on this occasion, that we can celebrate a series of successes in European integration and that all is well as a result of it. But unfortunately, all is not well. What is more, in various parts of the European population there seems to be a sentiment today where people don't see themselves so much as beneficiaries of European integration but rather as victims of it. In some countries, this sentiment is brought on by the economic crisis and the austerity measures, in other countries by the fact that public funds are being committed to bailouts elsewhere on the continent. In this, there is a great deal of misconception, and a tendency to lose sight of the fact that, on either side, the people are not victims of the EU as such but victims of bad policies, or bad implementation of correct policies, both at national and EU levels.

The challenge is to abandon the bad policies and to replace them by better ones, rather than to abandon the integration in itself. The problem of legitimacy-and it is a rather serious problem - arises because bad policies have not been corrected soon or effectively enough and, as a result, a situation has arisen where huge decisions are being forced in a quick order by events rather than being taken by way of reflection, proper debate and informed popular support. When problems have reached a crisis point, it is harder to even find the good policies or to pursue them successfully. In any case, it seems important to make and bring out a distinction between bad policies that require correction and the EU as an institutional framework as such. The latter does not lose its value because of misguided policies at national and European levels.

This being said, we can perhaps be grateful that we are just lawyers and not economists. Lawyers obviously hold law in high regard, but they can also have a tendency to overestimate the results that can be achieved through law as such. Maybe the economic hardship can help put things into proper perspective.

Law is the infrastructure, not the action. Law is the skeleton, not the muscle of a society. If Europe is stagnating, or even regressing, in terms of its potential for a successful and sustainable economic base and social order, it cannot be saved by its 
laws alone. One cannot legislate against economic decline. We need the skeleton but also muscle strength. Smart laws can support, organise and help distribute output and welfare, but they don't create or preserve it. We lawyers, as well as the citizens as the ultimate stakeholders, will be wise to appreciate both the importance of law and its limits.

In Finland, we had a severe economic crisis twenty years ago, and recovery demanded extensive austerity measures over many years. At the same time, the national constitution of fundamental rights was reformed and expanded. It is as if the government sought a kind of appeasement by saying to the people: "sorry, we've run out of money but instead, we'll give you better rights". Obviously, however, rights need to be backed up by resources, otherwise they are empty rights. In the EU context, the situation seems a bit similar: the financial crisis has exposed a debt crisis, which is turning into an economic recession, at the same time as the Charter of Fundamental Rights has emerged as a legally binding instrument. This does not detract from the fact that muscle cannot be replaced by added bone.

In our concern for the citizens, we lawyers should keep in mind to focus not just on rights as such but on the outcomes of rights. Law in books can be fine but it is law in action that determines the real position of our citizens. There can be a temptation to expand rights without serious attention to implementation. Such rights remain more or less illusory. Good intentions with weak implementation are not a recipe for real progress. This problem is accentuated when the responsibility for determining the content of rights and the implementation of such rights are at different levels, which is largely the case for European human and fundamental rights in particular.

If law is the skeleton, then rule of law is the spine. Especially with free movement and the principle of mutual recognition, which is based on common standards and mutual confidence, the actual state of rule of law throughout the Union becomes a matter of common interest and concern. Mutual recognition can only be sustained if each Member State lives up to rule of law standards both as a matter of principle and as a matter of actual practice. This is a fundamental requirement from the point of view of European citizens who make use of their free movement rights. I do hope that a diligent respect for rule of law principles can be ensured throughout the EU. Otherwise, the area of security, freedom and justice cannot function as it should.

In recent times, there have also been some signs of tensions that can arise in the present multipolar system of European law. The way in which the European Court of Human Rights has developed its case-law on Article 8-regarding respect for family life-in connection with child-abduction cases seems to run counter to the basic ideas of the Hague Convention regulating this matter on a world-wide basis. What is more, this new line of case-law from Strasbourg has a tendency that would undermine the application of the relevant EU law, namely the Brussels II bis regulation. This issue goes to the heart of EU law principles, namely the principle of mutual recognition and the division of jurisdiction in family cases as set out in the regulation. The result is great legal uncertainty and confusion for the European citizens and the children concerned-i.e. just the contrary of what is intended by the policies that have been adopted. It is to be hoped that some correctives can be found in order to avoid further problems in this field.

To conclude, I wish to reiterate my warmest congratulations to ERA, and my best wishes for its future. ERA offers medicine against ignorance about European law, 
which is still a major problem throughout the Member States. It offers valuable support for the professional development of lawyers in matters of European law, and it offers medicine against silo mentalities - across geographical, linguistic, institutional and professional borders. This is a very important mission.

Last but not least, I extend my warmest thanks to the wonderfully competent and dedicated staff, as well as to all those who serve and have served in the governing bodies, plus the Friends of ERA, without whom we wouldn't be here. 